\title{
ANIMAL PRODUCTION SYSTEMS AS A SELECTIVE ENVIRONMENT FOR ANTIBIOTIC RESISTANCE GENES
}

\author{
Jerneja AMBROŽIČ AVGUŠTIN ${ }^{1}$
}

Received May 23, 2012; accepted June 10, 2012. Delo je prispelo 23. maja 2012, sprejeto 10. junija 2012.

\begin{abstract}
Animal production systems as a selective environment for antibiotic resistance genes

In the last decade antibiotic usage in animal production systems has received a considerable public attention. The use, overuse and misuse of antibiotics provided an excellent environment for the selection and dissemination of antibiotic resistant bacteria and resistance genes across a wide diversity of bacteria, mainly through horizontal gene transfer. Resistance genes move between animal and human bacteria mainly through the food chain. Thus resistance generated in animal production environments could result in the loss of effectiveness of antibiotics used for the treatment of human diseases. The increasing threat of emerging bacterial pathogens resistant to a variety of antibiotics and the economic and human burden have moved the legislators in EU to ban antibiotic usage in animal food production as growth promoters in 2006 and recently proposed further non-binding recommendations to ban antibiotics for prophylactic use too. The costs for such actions will presumably be much lower in comparison to the costs of leaving the issue as it is. However, in non EU countries such measures have not been adopted yet. The mechanisms and examples of antibiotic resistance development and dissemination are described, focusing on antibiotics used both in human and veterinary medicine and animal food production.
\end{abstract}

Key words: animal production / antibiotics / resistance genes / food

\section{INTRODUCTION}

The emergence of antibiotic resistant bacteria have become one of the major challenges of the health care systems in the world, both from the point of economic and human costs (Bush et al., 2011). The estimated extra

\section{Živinorejska proizvodnja kot selektivno okolje za rezistenčne gene}

V zadnjem desetletju je uporaba antibiotikov v živinoreji pritegnila pozornost širše javnosti. Nenadzorovana, prekomerna in nenamenska uporaba antibiotikov je, predvsem preko mehanizma horizontalnega prenosa genov, omogočila selekcijo in širjenje proti antibiotikom odpornih bakterij in genov z zapisi za odpornost. Prenos odpornih bakterij oziroma genov z zapisi za odpornost med človekom in živalmi poteka predvsem preko prehranjevalne verige. Posledično lahko odporne bakterije ali geni z zapisom za odpornost, ki izvirajo iz živinorejskega okolja, zmanjšajo učinkovitost zdravljenja bakterijskih okužb $\mathrm{z}$ antibiotiki pri človeku. Vse večja grožnja pojavljanja novih večkratno odpornih patogenih bakterij, ter kot posledica vpliv na zdravje ljudi in tudi ekonomska škoda, so pripeljali do odločitve Evropske skupnosti, da od leta 2006 prepove uporabo antibiotikov kot pospeševalcev rasti $\mathrm{v}$ živinoreji. Nedavno pa so sprejeli tudi priporočilo, po katerem naj se antibiotikov v živinoreji ne bi uporabljalo več niti za profilakso. $V$ večini držav izven EU podobne zakonodaje še niso sprejeli. $V$ tem članku so opisani primeri razvoja in pojavljanja odpornosti proti antibiotikom, ki se uporabljajo tako $v$ humani medicini in veterini, kot

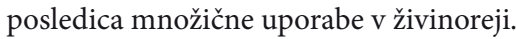

Ključne besede: živinoreja / antibiotiki / odpornost / geni / živila

hospital costs and costs due to productivity losses associated with infections by multi-drug resistant bacteria in Europe in 2007 alone exceeded $€ 1.5$ billion, and caused over 25.000 deaths (ECDC\&EMEA, 2009), whereas in the United States the established costs are several fold higher (Roberts et al., 2009; IDSA 2011). Three impor-

1 University of Ljubljana, Biotechnical Faculty, Department of Biology, Večna pot 111, SI-1000 Ljubljana, Slovenia, e-mail: jerneja.ambrozic@bf.uni-lj.si 
tant issues should be considered when it comes to antibiotic resistances: (i) what do we know about the reservoirs of existing resistance genes, (ii) how and where novel resistance genes emerge, and (iii) how antibiotic resistance genes spread from environmental and harmless organisms to pathogenic bacteria. Although hospitals were traditionally considered to be the major selective environment of antibiotic resistant bacteria and resistance genes, it is becoming clear, that other reservoirs of resistance genes must exist. Antibiotics have been used in food animal production systems since the late 1940s. This constant selective pressure favored the spread of resistance genes through horizontal gene transfer among commensal and/or pathogenic bacteria. The question is raised whether possible links between antibiotic use in animal-food production systems and resistant commensal or pathogenic bacteria in humans exist. Recent findings dealing with this subject are discussed in this review paper.

\section{USE OF ANTIBIOTICS IN ANIMAL- FOOD PRODUCTION SYSTEMS}

Agriculture, and within it animal husbandry or in more modern terms animal-food industry, creates anthropogenic ecosystems (Jackson and Piper, 1989), which are defined as collection of organisms and physical structures under human control and manipulation (Davis et al., 2011). Unlike in earlier farm-based practices, modern industrialized animal-food production (AFP) employs methods that impact natural selection (genetic modification), quality of animal life (by constraining animal space and interactions), landscape (vast stables and slaughter-houses), and ecology (animal waste disposals)
(De Soet, 1974). In such industrialized anthropogenic environments humans control the system through application of antimicrobial substances - antibiotics ${ }^{1}$, on a regular basis (Silbergeld et al., 2008).

Antibiotics are administered in AFP systems for three types of use, therapeutic, prophylactic and subtherapeutic (Boecker, 2003). Therapeutic use is aimed at curing infected animals and whenever groups of animals are treated, be it through injection, feed or water, it is plausible that some animals that are not diseased will also receive antibiotics. The prophylactic use is aimed at preventing a disease. The antibiotics are regularly administered through feed to groups of animals which are not diseased yet, but some may be subclinical or can be expected to become infected. The sub-therapeutic use is aimed at growth promotion or increased feed efficiency and the antibiotics are administered in lower doses through feed. In all three instances it can be expected, that (i) animals which are not diseased will also be treated with antibiotics, and that (ii) the contact of commensal gut microbes with the antibiotic substances will be maintained on a prolonged scale.

The benefits that can be achieved through administration of antibiotics in AFP, and were most likely the main cause for such practices, can be described in three categories. First, the use of antibiotics will likely lead to healthier animals and to the reduction of animal products contaminated by undesired (pathogen) microbes, thus it will improve the food safety and quality (Boecker, 2003; CDUFA, 1999). Second, the production cost of AFP will decrease due to productivity gains and also through reduction of loses due to diseased animals (Bolduan,

\footnotetext{
1 Originally the term antibiotic was used only for substances produced by $\mathrm{mi}-$ croorganisms; nowadays this term is also used for semisynthetic or synthetic antimicrobial substances (author's comm.)
}

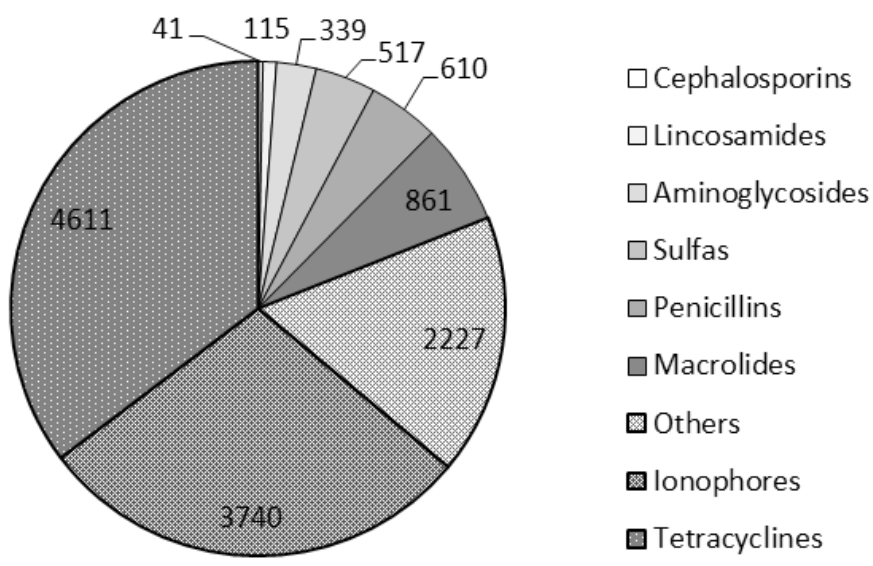

Figure 1: The amount of antibiotics used in animal food production (AFP) in USA in 2009 in tons. Adapted from FDA (2009) Slika 1: Količina antibiotikov, ki so jih uporabili v živinoreji v ZDA v letu 2009 v tonah. Prirejeno po FDA (2009) 
1998). The mechanisms leading to growth promotion in animals comprise amongst others the direct effects of antibiotics on various biochemical processes and pathways, such as nitrogen excretion, protein synthesis or methanogenesis and also prevention of colonization and reduction of subclinical populations of pathogens in animals' digestive tract which may present the so called metabolic drain. And third, the use of antibiotics may, as a consequence of the achieved increases in productivity, make possible the optimization and increased efficiency in the AFP and thus contribute to environmental protection issues, for example through reduced emissions of nitrogen, phosphorus and methane (Jamroz et al., 1998).

It has been estimated that more than a million metric tons of antibiotics have been released into the biosphere during the last 50 years globally (Mazel and Davies, 1999). Improvement in animal growth due to antibiotics was first described in the mid-1940s and within five years the addition of growth promoting antibiotics in AFP systems became common practice (Moore et al., 1946). In 2009, $80 \%$ of antibiotics used were allocated to non-human use in United States, of those the majority (64\% from total use) to healthy animals for growth promoting purposes (FDA, 2009). Almost $65 \%$ of antibiotics used in AFP in the United States in 2009 were from the class of tetracyclines and ionophores (Fig. 1), according to sales and distribution data reported by FDA (2009).

\section{THE EMERGENCE OF ANTIBIOTIC RE- SISTANT BACTERIA}

\subsection{MECHANISMS OF ANTIBIOTIC RESISTANCE DEVELOPMENT AND DISSEMINATION}

Antibiotic resistance is ancient as antibiotic synthesis and resistance genes were already present in natural environments long before the therapeutic use of antibiotics (D'Costa et al., 2011). Most resistance genes are homologous to those found in antibiotic-producing microorganisms from the soil (e.g. bacteria from the genera Actinomyces and Streptomyces) which harbor resistance genes for self- protection that are often clustered in the same operon as the genes for the synthesis of antibiotics (Cundliffe et al., 2001). However, the wide spread of antibiotic resistant bacteria and selection for novel resistance genes occurred only after antibiotics became widely used in human and veterinary medicine. In particular, the long term use of sub-therapeutic concentrations is regarded as one of the major factors responsible for the development of resistance, exerting a potent selective pressure for the emergence of resistant clones that already pre-existed in the bacterial population (Gullberg et al., 2011, Corpet et al., 1989; Bergogne-Berezin, 1997).

Bacterial resistance can be divided into (i) inherent or intrinsic resistance and (ii) acquired resistance. In intrinsic resistance a bacterium is normally not susceptible to an antimicrobial due to the inability of the drug to enter the bacterial cell or the absence of its target site. In acquired resistance a bacterium is normally susceptible to a particular drug, but can become resistant through mutations, resistance gene/s acquisition by horizontal gene transfer or both. Horizontal gene transfer enables direct exchange of genetic information between microbes through three main mechanisms: conjugation, transduction and transformation. It allows a bacterial population to develop resistance at a rate that is significant higher than would be afforded by mutations. The main vehicles for the dissemination of resistance genes among Gramnegative bacteria are transmissible-conjugative plasmids which can be transferred between different, even unrelated bacteria. On such plasmids, special genetic structures such as transposons and integrons may reside. Transposons are DNA sequences, able to encompass several resistance genes that can autonomously move from one location on the genome to another. Integrons are assembly platforms that incorporate so called gene cassettes (Mazel, 2006; Stokes and Hall, 1989). Two major groups of integrons have been described: »chromosomal integrons « and "mobile integrons «. Chromosomal integrons are located on chromosomes of hundreds of different bacterial species, and some of them have also been termed »super-integrons" as they can carry up to 200 gene cassettes. Mobile integrons are located on mobile genetic elements such as transposons or plasmids and are capable to disseminate among bacteria. They contain a limited number of gene cassettes which usually encode antibiotic-resistance determinants (Stalder et al., 2012). Simultaneous resistance to three or more classes of antimicrobials by various resistance mechanisms encoded by different genes is defined as multiresistance. In bacteria, it is generally attributed to the acquisition of plasmids, transposons and integrons encoding different resistance genes. Although use of antibiotics leads to selection for a new type of resistance quite rapidly, removal of the antibiotic reverses this trend only slowly (Morell, 1997). Either resistance doesn't influence the bacterial "fitness", and so resistant bacteria can continue to propagate with the same rate as susceptible bacteria, or genetically linked resistance genes are co-selected in the presence of antimicrobials. It is known now that resistances to particular antibiotics will not easily disappear, even if the drug is not used for a long period of time (EMEA, 1999). 


\subsection{TRANSFER OF ANTIBIOTIC RESISTANCE FROM ANIMALS TO HUMANS}

Antibiotics can trigger the selection of resistant bacteria in animal production systems by two main routes. First, directly through application of the drugs through animal feed, entering animal body and accumulating in the gastrointestinal tract executing a selective pressure on intestinal commensal and/or pathogenic bacteria. And second, through subsequent excretion of absorbed antibiotic residues and their metabolites via animal urine and feces into the environment. $30-80 \%$ of antibiotics fed to animals as growth promoters may be excreted as waste because of poor absorption. Antibiotic-laden manure can be used to fertilize crop-lands and so antibiotics enter the soil or groundwater, streams, lakes or rivers. Subsequently, in any of these ecosystems, traversed by the drugs or their residues, antibiotic resistant bacteria can emerge and then travel along the same route (Fig. 2). Thus they can be transmitted to humans directly, via the food chain or environmental route. Resistant bacteria may colonize humans and/or may become sources of antimicrobial resistance genes for human endogenous microbiota (Trobos 2009). Through the horizontal gene transfer mechanisms, the resistance capability can get spread at any stage of the route rapidly across a wide diversity of bacteria (Aminov, 2011). Additionally, DNA sequences containing antibiotic resistance genes have been found in commercial antibiotic preparations $(\mathrm{Lu}$, 2004).

\subsection{THE COPYBOOK CASE: RESISTANCE TO TET- RACYCLINES}

Tetracyclines, including chlortetracycline, tetracycline and oxytetracycline have been the most common antibiotics used in AFP. It was in the late 1940s when T.H. Jukes discovered that young poultry fed fermented ration containing Streptomyces aureofaciens, which was used to produce chlortetracycline, showed a dramatic increase in weight gain (Wise, 2007). The use of chlortetracycline and subsequently oxytetracycline, as feed additives without veterinary prescription was approved in the United States by the Food and Drug Administration in 1951, followed by European countries in the 1950s and 1960s (Chopra, 2001; Castanon, 2007). In the following years, tetracyclines have been widely used for therapeutic purposes and at sub-therapeutic concentrations for growth enhancement in many countries. During the 1960s concerns arose about possible hazards to human and animal health. Researchers at that time agreed that the only hazard that could be foreseen is the effect of antibiotics on bacterial populations (e.g. development of resistance) (Braude, 1978). Indeed several reports about resistant bacteria, especially strains of Salmonella asso-

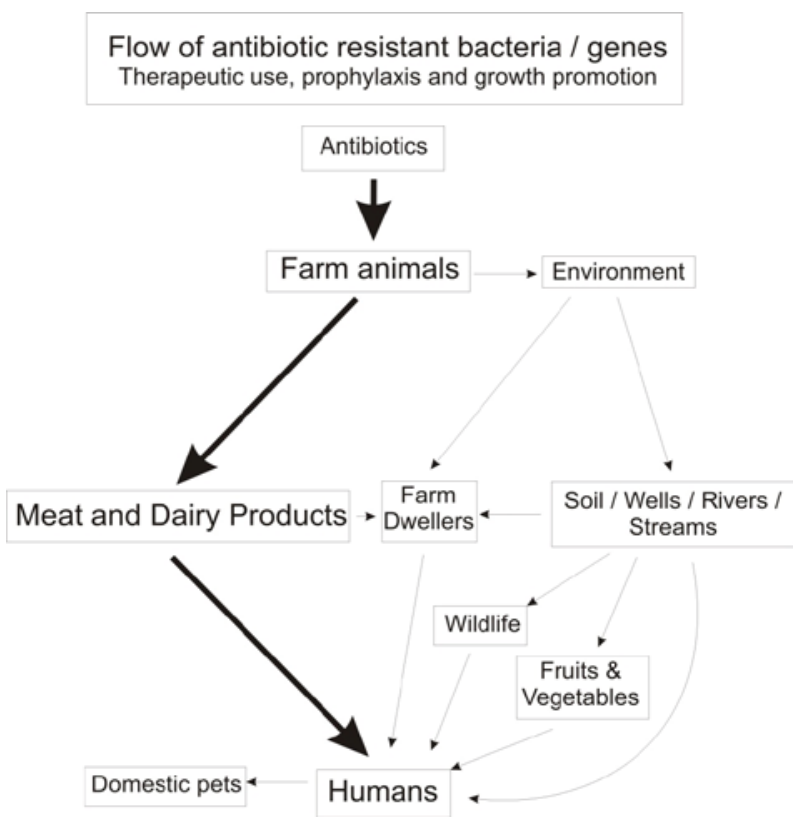

Figure 2: The flow of antibiotic resistant bacteria and genes in animal-food production systems from farm animals to humans. Adapted from Wilson and Tam (APUA 2010)

Slika 2: Prenos proti antibiotikom odpornih bakterij in genov od domačih živali na ljudi v živinoreji. Prirejeno po Wilson in Tam (APUA 2010) 
ciated with calf disease and the occurrence of transferable resistance, were published. As a consequence a Joint Committee on the use of antibiotics in animal husbandry and veterinary medicine under the leadership of M.M. Swann was set up in the United Kingdom. The Swann Committee concluded in 1969 that the administration of antibiotics, particularly at sub-therapeutic levels, posed certain hazards to human and animal health and recommended that antibiotics available without prescription in animal feed should have little or no application as therapeutics agents in man (Manten, 1963; EMEA, 1999). The European Union banned the use of tetracycline as growth promoters in 1976 (Directive 73/264) (Castanon, 2007; Cogliani, 2011). However, in the United States and many other countries tetracyclines are still allowed to be used as feed additives. It was in 1976 when Levy and colleagues described the transfer of tetracycline resistance genes between $E$. coli strains from chicken to chicken and from chicken to humans. A retrospective study of 1.729 E. coli isolates recovered from human and food animal samples during 1950-2002 conducted by Tadesse and colleagues (2012) revealed that tetracycline resistance was the most common type of resistance observed and the most prevalent resistance in animal isolates (71.1\%). Thus the widespread resistance has limited the clinical use of tetracyclines which were partly replaced by other broad-spectrum antibiotics with a different mode of action e.g. quinolones (Thaker, 2010).

\subsection{EMERGENCE OF VANCOMYCIN RESISTANT ENTEROCOCCI}

The evolution and dissemination of resistance through overuse and misuse of antibiotics is exampled by the use of avoparcin, a glycopeptide antimicrobial agent related to vancomycin. Avoparcin has been used in Europe intensively as a growth promoter in animal feeds from the early 1970s for more than two decades resulting in the uptake of glycopeptide resistance genes by animal commensal bacteria, which were subsequently transferred to humans. Vancomycin resistant enterococci (VRE), which are known for their natural ability to acquire and exchange genetic elements encoding antibiotic resistance, have been isolated from pigs, calves and turkeys fed with avoparcin supplemented food. Humans who have come into close contact with these animals carried identical clones that have been found in animals. In addition, genotypically identical transposons, containing the van $A$ gene cluster have been identified in enterococci from animals and farmers (Stobberingh et al., 1999). Since infections with VRE in immunodeficient humans may be life-threatening due to a limited choice of alter- native treatment they represent a serious public health concern (Bonten et al., 2001). As a consecutive, the European Union banned the use of avoparcin in animal feed in 1997. After that the prevalence of VRE in broiler chickens and healthy humans decreased in several European countries (Heuer et al., 2002). The immense importance of horizontal gene transfer of antibiotic resistance genes was subsequently demonstrated by an in-human transmission of the vanA gene from Enterococcus faecalis to Staphylococcus aureus resulting in vancomycin resistant S. aureus (VRSA) (Chang et al., 2003). However, lessons learned from the emergence of VRE in Europe (1986) and the United States (1987) in 1986 and 1987, were not yet implemented appropriately in mass animal food production where the usage of potent drugs such as fluoroquinolones and the third and fourth generation cephalosporins has even increased over the last decade, predominantly in pig and broiler chicken productions.

\subsection{RESISTANCE TO FLUOROQUINOLONES}

Fluoroquinolones are fully synthetic broad-spectrum antimicrobial agents widely used in human and veterinary medicine. Resistance to this class of antibacterials is predominantly caused by mutations in the chromosomal genes that code for DNA gyrase and/or DNA topoisomerase IV, the target enzymes, and/or mutations resulting in alterations in drug accumulation. The spread of fluoroqinolone resistance is therefore mainly clonal. Fluoroquinolones are frequently prescribed empirically for the treatment of diarrheal disease, including campylobacteriosis. Several studies suggested that the use of fluoroquinolones in AFP has triggered the selection of fluoroquinolone resistant campylobacter isolates in animals and their subsequent spread via the food chain to humans. Campylobacter jejuni is a part of the gastrointestinal tract commensal microbiota in poultry, ruminants and pigs. In humans, $C$. jejuni is a common agent of bacterial diarrheal disease, however. Infection of humans can occur via direct contact with animal feces or, much more commonly, via ingestion of contaminated, undercooked meat or raw milk. Smith and colleagues (1999) noted a significant increase in quinolone resistant $C$. jejuni infections in humans that were acquired domestically, and proposed an association between the resistant strains and the use of fluoroquinolones (sarafloxacin in 1995 and enrofloxacin in 1996) in poultry in the United States. Legal restrictions in order to reduce the use of fluoroquinolones in food animals have been introduced in 2003 in Denmark (Evans and Wegener, 2003) and subsequently in the United States with the withdrawal of enrofloxacin for the use in poultry (FDA, 2005). Conse- 
quently the prevalence of ciprofloxacin resistance in $E$. coli from Danish broiler meat decreased from 10\% in 2003 to $4.5 \%$ in 2006 (Hammerum et al., 2007). Recently, three plasmid-mediated quinolone resistance (PMQR) mechanisms mediating low-level fluoroquinolone resistance have also been described. The first comprises $q n r$ genes that encode target protection proteins of the pentapeptide repeat family. Five $q n r$ genes, namely $q n r A$, $q n r B, q n r S, q n r C$ and $q n r D$ and their allelic variants have been described so far. The second mechanism involves the $a a c\left(6^{\prime}\right)-I b-c r$ gene, which encodes a new variant of the common aminoglycoside acetyltransferase and the third mechanism involves the fluoroquinolone efflux pumps QepA and OqxAB (Ambrožič et al., 2007, Poirel et al., 2012). Numerous surveillance reports of the prevalence of PMQR genes in food animals have been published recently. Szmolka and colleagues (2011) have identified PMQR genes in Escherichia coli strains of $34 \%$ piglets in two large pig farms in Romania. Six isolates carried the qnrS1 gene on IncN plasmids. DNA sequences flanking the qnrS1 gene showed high homology with corresponding regions of a plasmid isolated from Salmonella Infantis from chicken carcass and $\mathrm{IncN}$ plasmids from human clinical E. coli isolates. They suggest that transfer of $q n r S 1$ plasmids can occur between Salmonella and E. coli of animal and human origin, with pigs being one of the potential reservoirs (Szmolka et al., 2011). High prevalence of fluoroquinolone resistance in human and animal E. coli isolates have also been reported from China, again most likely due to the overuse of quinolones as growth promoters and therapies in food animals (Xiao et al., 2008). Zhao and colleagues (2010) demonstrated a high prevalence of $o q x A B$ in $E$. coli isolated from animals, farmworkers and environmental samples including surface soil, sewage, drinking water and pond water samples. On the basis of the same PFGE pattern observed in E. coli isolates from animals and farmworkers they suggested the clonal transmission of oq $x A B$ positive $E$. coli between humans and animals. Additionally the same resistance plasmids were found in clonally unrelated isolates (Zhao et al., 2010). Cerquetti and colleagues (2009) screened 73 poultry E. coli isolates for the presence of PMQR genes. One isolate harbored a plasmid encoding the qnrS1 gene and resembled the same resistance region and plasmid scaffold sequence as the plasmid previously described in two different Salmonella enterica strains of animal origin, suggesting genetic exchanges among Salmonella and E. coli strains of animal origin. Although PMQR genes confer only low-level resistance they are transferable between different species and genera and enable the selection of additional chromosome mutations leading to higher resistance levels. Thus PMQR of enterobacteria is an emerging concern in human and veterinary medicine, nonetheless because PMQR genes are frequently encoded by the same plasmid as ESBL and/or AmpC genes and are co-selected with the use of $\beta$-lactam antibiotics.

\subsection{RESISTANCE TO $\beta$-LACTAM ANTIBIOTICS}

$\beta$-lactams are by far the most used type of antimicrobials used in human medicine. The major mechanism of resistance to $\beta$-lactam antibiotics among Gram-negative bacteria is the production of $\beta$-lactamase enzymes which are able to hydrolyze the $\beta$-lactam ring of these antibiotics. Although such enzymes have protected bacteria against naturally occurring $\beta$-lactams long before the clinical use, it became clear that the numbers and varieties of $\beta$-lactamases have increased dramatically since the introduction of modern (modified) penicillins and cephalosporins in human and veterinary usage. A single base change in the gene for a $\beta$-lactamase can change the substrate specificity of the enzyme. Such changes occurred and were detected frequently after 1950 in common, clinically relevant Gram-negative bacteria, especially from the family Enterobacteriaceae. Stepwise selection of variants within the so called "extended $\beta$ - lactamases" included first enzymes that efficiently hydrolyzed ampicillin and some first-generation cephalosporins. These were followed by enzymes with an enlarged hydrolytic spectrum denoted "broad-spectrum $\beta$-lactamases" or BSBLs. Increasing treatment failure due to beta-lactam resistance lead to the introduction of several new antimicrobials in the 1980s, among others the "third- and fourth-generation" of cephalosporins. Soon after the introduction, $\beta$-lactamases capable of hydrolyzing the $3^{\text {rd }}$ and subsequently the $4^{\text {th }}$ generation of cephalosporins were discovered and termed "extendedspectrum $\beta$-lactamases" or ESBLs. The BSBL progenitors of ESBL enzymes were enzymes denoted TEM-1, TEM2 and SHV-1. Numerous mutations in genes coding for these enzymes resulted in a variety of ESBL enzymes differing in their structure and hydrolytic spectrum. The majority of them are encoded on transferable genetic elements enabling their dissemination throughout Gramnegative bacteria.

In 1990 Bauernfeind and colleagues described an $E$. coli clinical isolate which produced a non-TEM and nonSHV ESBL. The enzyme was named CTX M-1, creating the so-called "cefotaximase family that is now divided into five groups (CTX-M-1, CTX-M-2, CTX-M-8, CTXM-9 and CTX-M-25). The origins of CTX-M enzymes are most likely chromosomally encoded enzymes from different species of the genus Kluyvera. The genes have been mobilized independently several times on different plasmids (Canton et. al., 2012). Additionally, it is known 
that chromosomally encoded $\beta$-lactamases conferring at least low level resistance to $\beta$-lactams are common in Gram-negative bacteria and almost all Enterobacteriaceae. In fact the first reported enzyme in the 1940 s destroying penicillin was the so-called AmpC $\beta$-lactamase discovered in E. coli. Stepwise mutations, predominantly in the regulatory genes and to a lesser extent in the structure genes, lead to an increased production of these enzymes conferring clinically relevant resistance levels and an enlarged hydrolytic activity (Jacoby, 2009). Genes encoding these enzymes have apparently moved from the chromosomes onto mobile plasmids and subsequently into different bacterial species (Philippon et al., 2002). The first plasmid-encoded encoded AmpC genes were discovered in 1989 (Papanicolaou et al., 1990). Since ESBL and AmpC genes can be transferred horizontally they have spread globally within the last decade and now represent a major public health concern.

Recently, it was proposed that dissemination of resistance to $\beta$-lactams in the community could be enhanced due to the spread via food and from animal production environments. Indeed, several papers described the occurrence of E. coli and other bacterial species producing ESBL and/or AmpC enzymes in food producing animals such as poultry, cattle, swine, horses and rabbits in different countries in Europe. Geser and colleagues (2012) screened 334 fecal samples collected from healthy animals, including 59 pigs, 124 cattle, 58 sheep and 93 chickens at slaughter in Switzerland for the presence of ESBL genes. Surprisingly, 15.3\% pigs, $13.7 \%$ cattle, $8.6 \%$ sheep, and $63.4 \%$ chickens carried ESBL producing bacteria, predominantly E. coli. The prevalence was higher than in healthy Swiss human population, implying a reservoir of ESBL producers in farm animals. Dolejska and colleagues (2011) demonstrated the presence of ESBL producing E. coli on eight out of forty surveyed turkey farms. A total of twenty-five ESBL E. coli were isolated from fecal samples taken from different flocks. The major type of ESBLs reported in a number of surveys from United Kingdom (Horton et al., 2011), the Netherlands (Dierikx et al., 2010), Denmark (Cavaco et al., 2008), Spain (Blanc et al., 2006), Germany (Rodriguez et al., 2009), Poland (Wasyl et al., 2012), Italy (Bortolaia et al., 2010), and France (Meunier et al., 2006; Girlich et al., 2007 ) is the CTX-M group. Riano and collegous (2006) found four ESBL-producing isolates (one porcine, two from broilers and one from a laying hen) of Salmonella enterica out of 556 screened fecal samples of healthy food animals at a slaughterhouse in Spain. In the Dutch surveillance program of antibiotic resistance in 2006, $359 \mathrm{~S}$. enterica isolates were obtained from various poultry sources. Fifteen of them produced various ESBLs whereas one isolate produced an AmpC (Dierikx et al.
2010). Recently, concerning results were reported by Leverstein-van Hall and colleagues (2011). They compared E. coli isolates from retail chicken meat, food-producing animals and humans and found out that $19 \%$ of the human isolates carried ESBL genes on plasmids that were genetically indistinguishable from those obtained in poultry isolates. Further, $94 \%$ of the retail chicken meat was contaminated with ESBL-producing E. coli, of which $39 \%$ had the same genotypes as the ones found in human isolates. On the basis of their results they suggest a possible transmission of ESBL-producing E. coli from poultry to humans, most likely through the food chain. Additional data describing the occurrence of ESBL and/ or AmpC enzymes in food animals and/or food can be retrieved from the EFSA scientific opinion on the public health risks of bacterial strains producing extendedspectrum $\beta$-lactamases and/or AmpC $\beta$-lactamases in food and food-producing animals (EFSA, 2011). As seen with glycopetides and fluoroquinolones and other not mentioned classes of antimicrobials, the use of cephalosporins in food-producing animals is apparently a crucial selective factor for the appearance of ESBL and AmpC producing bacteria in animals (Cavaco et al., 2008). Since the intestinal microbiota of food producing animals on large-scale farms is commonly under selective pressure caused by the use of antimicrobial agents in treatment or prevention of bacterial infections (Schwarz et. al., 2001) it can act as a large reservoir for resistant bacteria and resistance genes. Bacteria tightly packed together represent an ideal site for "in vivo" horizontal gene transfer between different bacterial species and genera and even unrelated bacteria of the endogenous microbiota and the exogenous bacteria which are usually transient and are shed with the faces. Antimicrobial resistant bacteria (e.g. E. coli) are then transmitted to humans directly, via food contaminated at slaughter or due to environmental spread of resistant bacteria (e.g. manure). This mechanism is very efficient as microorganisms can acquire ready-to-use set of genes coding for multiple antibiotic resistance in a single step through the acquisition of a plasmid or conjugative transposon. Because of the critical importance in human and veterinary medicine resistance to cephalosporins is declared a special public health concern (FAO/WHO/OIE, 2008).

\section{CONCLUSION}

Antibiotics used for growth promotion or preventing/ treating bacterial infections have executed an immense pressure for the selection of antibiotic resistant commensal and/or pathogenic bacteria in food-animals and the animal-production environment, including spe- 
cies from genera Salmonella, Escherichia, Campylobacter and Enterococcus. These bacteria may also colonize humans and/or become sources of antimicrobial resistance genes for human endogenous microbiota (Trobos et al., 2009). At the end, certain bacterial infections in humans (and animals) which could normally be treated successfully by available antibiotics are turning out to be untreatable. Thus the crisis of antibiotic resistance in human (and veterinary) medicine has led to considerable reassessment of all aspects of antibiotic usage in animalfood production, especially for growth promotion and disease prevention. For this reason the European Union restricted the use of most antibiotics for growth promotion in 1999 and banned it completely in 2006. However, the United States and many other countries outside the EU have not adopted this broad policy yet, although the WHO, the American Public Health Association, and the American Medical Association have urged a ban at least on growth-promoting antibiotics. Major achievements were the ban of enrofloxacin for poultry treatment in 2005 and the prohibited use of cephalosporins (except for the first generation cephapirin) for disease prevention, growth promoting, improving feed efficiency and other extra labeled use in cattle, swine, chickens and turkeys since April 2012 (FDA: 21 CFR Part 530; Doc. No. FDA-2008-N-0326). The development and spread of antibiotics resistance in bacteria is not preventable but can and should be controlled.

When the European Parliament resolution (27 October 2011) on the public health threat of antimicrobial resistance made non-binding recommendations for the EU and Member states, the Public Health Committee chair Jo Leinen stated: "The growing ineffectiveness of antibiotics is already a serious problem today and a potential health bomb for the future. We need a clear EU and international strategy to prevent misuse in agriculture and medicine, as well as to encourage the development of new antibiotics. Member states should phase out their pre-emptive "prophylactic" use of antibiotics, further active ingredients used in veterinary medicines should be kept as separate as possible to reduce risks of resistance transferring between animals and humans and the so-called "last resort" antibiotics should be restricted for agricultural use to ensure that these are prioritized for fighting the most resistant infections in human healthcare" (cited: EU Parliament resolution B7-0538/2011).

\section{REFERENCES}

Ambrožič J., Keber R., Žerjavič K., Oražem T., Grabnar M. 2007. Emergence of the quinolone resistance-mediating gene $a a c\left(6^{\prime}\right)-I b-c r$ in extended-spectrum-beta-lactamase Klebsiella isolates collected in Slovenia between 2000 and
2005. Antimicrobial Agents and Chemotherapy, 51, 11: 4171-4173

Aminov R.I. 2011. Horizontal Gene Exchange in Environmental Microbiota. Frontiers in Microbiology, 2: 158

Bauernfeind A., Grimm H., Schweighart S. 1990. A new plasmidic cefotaximase in a clinical isolate of Escherichia coli. Infection, 18:294-298

Bergogne-Berezin E. 1997. Who or what is the source of antibiotic resistance? Journal of Medical Microbiology, 46: 461-464

Blanc V., Mesa R., Saco M., Lavilla S., Prats G., Miró E., Navarro F., Cortés P., Llagostera M. 2006. ESBL- and plasmidic class C beta-lactamase-producing E. coli strains isolated from poultry, pig and rabbit farms. Veterinary Microbiology, 118, 3-4: 299-304

Bolduan G. 1998. Fütterung der Absetzferkel ohne Leistungsförderer? LAF-Informationen, 6, 1: 73-80

Boecker A. 2003. Use of antibiotics in animal husbandry: Consumer protection, public health and the precautionary principle. In: Proceedings of the Annual Meeting of the German Association of Agricultural Economics and Rural Sociology (GEWISOLA), 39: 545-554

Bonten M.J.M., Willems R., Weinstein R.A. 2001. Vancomycinresistant enterococci: why are they here, and where do they come from? Lancet Infectious Diseases, 1: 314-325

Bortolaia V., Guardabassi L., Trevisani M., Bisgaard M., Venturi L., Bojesen A.M. 2010. High diversity of extendedspectrum beta-lactamases in Escherichia coli isolates from Italian broiler flocks. Antimicrobial Agents and Chemotherapy, 54, 4: 1623-1626

Braude R. 1978. Antibiotics in Animal Feeds in Great Britain. Journal of Animal Science, 46: 1425-1436

Bush K., Courvalin P., Dantas G., et al. 2011. Tackling antibiotic resistance. Nature Microbiology Reviews, 9: 894-896

Cantón R, González-Alba JM, Galán JC. 2012. CTX-M Enzymes: Origin and Diffusion. Frontiers in Microbiology, 3: 110

Castanon J.I.R. 2007. History of the Use of Antibiotic as Growth Promoters in European Poultry Feeds. Poultry Science, 86: 2466-2471

Cavaco L.M., Abatih E., Aarestrup F.M., Guardabassi L. 2008. Selection and persistence of CTX-M-producing Escherichia coli in the intestinal flora of pigs treated with amoxicillin, ceftiofur, or cefquinome. Antimicrobial Agents and Chemotherapy, 52, 10: 3612-3616

Cerquetti M., García-Fernández A., Giufrè M., Fortini D., Accogli M., Graziani C., Luzzi I., Caprioli A., Carattoli A. 2009. First report of plasmid-mediated quinolone resistance determinant qnrS1 in an Escherichia coli strain of animal origin in Italy. Antimicrobial Agents and Chemotherapy, 53, 7: 3112-3114

Chang S., Sievert D.M., Hageman J.C., Boulton M.L., Tenover F.C, Pouch Downes F., Shah S., Rudrik J.T., Pupp G.R., Brown W.J., Cardo D., and Fridkin S.K. for the Vancomycin-Resistant Staphylococcus aureus Investigative Team. 2003. Infection with vancomycin -resistant Staphylococcus aureus containing the vanA gene. New England Journal of Medicine, 348: 1342-1347

Chopra I., Roberts M. 2001. Tetracycline Antibiotics: Mode of 
Action, Applications, Molecular Biology, and Epidemiology of Bacterial Resistance. Microbiology and Molecular Biology Reviews, 65: 232-260

Cogliani C., Goossens H., Greko C. 2011. Restricting Antimicrobial Use in Food Animals: Lessons from Europe. Microbe, 6: 274-279

Corpet D.E., Lumeau S., Corpet F. 1989. Minimum antibiotic levels for selecting a resistant plasmid in a gnotobiotic animal model. Antimicrobial Agents and Chemotherapy, 33: 535-540

CDUFA 1999. The Use of Drugs in Food Animals - Benefits and Risks. Committee on Drug Use in Food Animals, Panel on Animal Health, Food Safety, and Public Health, National Research Council. Washington, D.C., National Academy Press.

Cundliffe E, Bate N, Butler A, Fish S, Gandecha A, Merson-Davies L. 2001. The tylosin-biosynthetic genes of Streptomyces fradiae. Antonie Van Leeuwenhoek. 79, 3-4: 229-34

D’Costa V.M., King C.E., Kalan L., Morar M., Sung W.W. L., Schwarz C., Froese D., Zazula G., Calmels F., Debruyne R., Golding G.B., Poinar H.N., Wright G.D. 2011. Antibiotic resistance is ancient. Nature, 477: 457-461

Davis M.F., Price L.B., Liu C.M.-H., Silbergeld E.K. 2011. An ecological perspective on U.S. industrial poultry production: the role of anthropogenic ecosystems on the emergence of drug-resistant bacteria from agricultural environments. Current Opinion in Microbiology, 14: 244-250

De Soet F. 1974. Agriculture and the environment. Agric Environ, 1: 1-15

Dierikx C., van Essen-Zandbergen A., Veldman K., Smith H., Mevius D. 2010. Increased detection of extended spectrum beta-lactamase producing Salmonella enterica and Escherichia coli isolates from poultry. Veterinary Microbiology, 26: 145, 3-4: 273-278

Dolejska M., Matulova M., Kohoutova L., Literak I., Bardon J., Cizek A. 2011. Extended-spectrum beta-lactamase-producing Escherichia coli in turkey meat production farms in the Czech Republic: national survey reveals widespread isolates with bla (SHV-12) genes on IncFII plasmids. Letters in Applied Microbiology, 53, 3: 271-277

EFSA. 2011. Panel on Biological Hazards (BIOHAZ); Scientific Opinion on the public health risks of bacterial strains producing extended-spectrum $\beta$-lactamases and/or AmpC $\beta$-lactamases in food and food-producing animals. EFSA Journal, 9, 8: 2322. Available online: http://www.efsa.europa.eu/en/efsajournal/doc/2322.pdf

EMEA. 1999. European Medicines Agency. Antibiotic Resistance in the European Union Associated with Therapeutic Use of Veterinary Medicines. Report and Qualitative Risk Assessment by the Committee for Veterinary Medicinal Products. 79 p. (http://www.ema.europa.eu/docs/en_GB/ document_library/Report/2009/10/WC500005166.pdf)

European Centre for Disease Prevention and Control (ECDC) \& European Medicines Agency (EMEA). 2009. Joint technical report: the bacterial challenge. Time to react. ECDCEMEA, Stockholm, $54 \mathrm{p}$.

Evans M.C., Wegener H.C. 2003. Antimicrobial growth promoters and Salmonella spp., Campylobacter spp. in poul- try and swine, Denmark. Emerging Infectious Diseases, 9: $489-492$

FAO/WHO/OIE. 2008. Joint FAO/WHO/OIE Expert Meeting on Critically Important Antimicrobials. Report of a meeting held in FAO, Rome, Italy, 26-30 November 2007. FAO, Rome, Italy, and WHO, Geneva, Switzerland

FDA (U.S. Food and Drug Administration). 2009. Summary Report on Antimicrobials Sold or Distributed for Use in Food-Producing Animals. Retrieved from http://www.fda. gov/downloads/ForIndustry/UserFees/AnimalDrugUserFeeActADUFA/UCM231851.pdf

FDA (U.S. Food and Drug Administration). 2005. FDA/CVM Proposes to Withdraw Poultry Fluoroquinolones Approval. 2000. Retrieved from: http://www.fda.gov/NewsEvents/ Newsroom/PressAnnouncements/2005/ucm108467.htm

Geser N., Stephan R., Hächler H. 2012. Occurrence and characteristics of extended spectrum $\beta$-lactamase (ESBL) producing Enterobacteriaceae in food producing animals, minced meat and raw milk. BMC Veterinary Research, 8: 21

Girlich D., Poirel L., Carattoli A., Kempf I., Lartigue M.F., Bertini A., Nordmann P. 2007. Extended-spectrum beta-lactamase CTX-M-1 in Escherichia coli isolates from healthy poultry in France. Applied and Environmental Microbiology, 73, 14: 4681-4685

Gullberg E., Cao S., Berg O.G., Ilbäck C., Sandegren L., Hughes D., Andersson D.I. 2011. Selection of resistant bacteria at very low antibiotic concentrations.. PLoS Pathogens, 7, 7: e1002158.

Hammerum A.M., Heuer O.E., Emborg H.D., Bagger-Skjøt L., Jensen V.F., Rogues A.M., Skov R.L., Agersø Y., Brandt C.T., Seyfarth A.M., Muller A., Hovgaard K., Ajufo J., Bager F., Aarestrup F.M., Frimodt-Møller N., Wegener H.C., Monnet D.L. 2007. Danish integrated antimicrobial resistance monitoring and research program. Emerging Infectious Diseases, 13,11: 1632-9

Heuer O.E., Pedersen K., Andersen J.S., Madsen M. 2002. Vancomycin-resistant enterococci (VRE) in broiler flocks 5 years after the avoparcin ban. Microbial Drug Resistance, 8: $133-138$

Horton R.A., Randall L.P., Snary E.L., Cockrem H., Lotz S., Wearing H., Duncan D., Rabie A., McLaren I., Watson E., La Ragione R.M., Coldham N.G. 2011. Fecal carriage and shedding density of CTX-M extended-spectrum $\beta$-lactamase-producing Escherichia coli in cattle, chickens, and pigs: implications for environmental contamination and food production. Applied and Environmental Microbiology, 77, 11: 3715-3719

IDSA (Infectious Diseases Society of America). 2011. Combating Antimicrobial Resistance: Policy Recommendations to Save Lives. Clinical Infectious Diseases, 52, S5: S397-S428

Jackson W., Piper J. 1989. The necessary marriage between ecology and agriculture. Ecology, 70: 1091-1993

Jacoby G.A. 2009. AmpC $\beta$-lactamases. Clinical Microbiology Reviews, 22: 161-182

Jamroz D., Skorupinska J., Orda J., Wiliczkiewicz A. 1998. Impact of antibiotic growth promoters on egg production and quality, as well as on $\mathrm{N}$ - and P-emissions of laying chicken. Archiv für Geflügelkunde, 62, 5: 200-208

Leverstein-van Hall MA, Dierikx CM, Cohen Stuart J, Voets 
GM, van den Munckhof MP, van Essen-Zandbergen A, Platteel T, Fluit AC, van de Sande-Bruinsma N, Scharinga J, Bonten MJ, Mevius DJ; National ESBL surveillance group. 2011. Dutch patients, retail chicken meat and poultry share the same ESBL genes, plasmids and strains. Clinical Microbioogy and Infection, 17, 6: 873-80

Levy S. B., FitzGerald G. B., A. B. Macone. 1976. Changes in Intestinal Flora of Farm Personnel after Introduction of a Tetracycline-Supplemented Feed on a Farm. New England Journal of Medicine, 295: 583-588

Lu K., Asano R., Davies J. 2004. Antimicrobial Resistance gene delivery in animal feeds. Emerging Infectious Diseases; 10: 679-683

Manten A.1963. The Non-medical Use of Antibiotics and the Risk of Causing Microbial Drug-resistance. Bulletin of the World Health Organisation, 29: 387-400

Mazel D., Davies J. 1999. Antibiotic resistance in microbes. Cellular and Molecular Life Sciences, 56: 742-754

Mazel D. 2006. Integrons: agents of bacterial evolution. Nature Reviews Microbiology, 4: 608-620

Meunier D., Jouy E., Lazizzera C., Kobisch M., Madec J.Y. 2006. CTX-M-1- and CTX-M-15-type beta-lactamases in clinical Escherichia coli isolates recovered from food-producing animals in France. International Journal of Antimicrobial Agents, 28, 5: 402-407

Moore P.R., Evenson A., Luckey T.D., McCoy E., Elvehjem C.A., Hart E.B. 1946. Use of sulfasuxidine, treptothricin, and streptomycin in nutritional studies with the chick. Journal of Biological Chemistry, 165: 437-41

Morell V. 1997. Antibiotic resistance: Road of no return. Science, 278: 575-576

Papanicolau G.A., Medeiros A.A., Jacoby G.A. 1990. Novelplasmid mediated $\beta$-lactamase (MIR-1) conferring resistance to oxyimino-and $\alpha$-methoxy $\beta$-lactams in clinical isolates of Klebsiella pneumoniae. Antimicrobial Agents and Chemotherapy, 34: 2200-2209

Philippon A., Arlet G., Jacoby G.A. 2002. Plasmid-determined AmpC-type beta-lactamases. Antimicrobial Agents and Chemotherapy, 46, 1: 1-11

Poirel L., Cattoir V., Nordmann P. 2012. Plasmid -mediated quinolone resistance; interactions between human, animal, and environmental ecologies. Frontiers in Microbiology, 3: $1-7$

Riaño I, Moreno MA, Teshager T, Sáenz Y, Domínguez L, Torres C. 2006. Detection and characterization of extendedspectrum beta-lactamases in Salmonella enterica strains of healthy food animals in Spain. Journal of Antimicrobial Chemotherapy, 58, 4: 844-7

Roberts R., Hota B., Ahmad I., et al. 2009. Hospital and societal costs of antimicrobial-resistant infections in a Chicago teaching hospital: implications for antibiotic stewardship. Clinical Infectious Diseases, 49: 1175-1184

Rodríguez I., Barownick W., Helmuth R., Mendoza M.C., Rodicio M.R., Schroeter A., Guerra B. 2009. Extended-spectrum $\beta$-lactamases and AmpC $\beta$-lactamases in ceftiofur-resistant Salmonella enterica isolates from food and livestock obtained in Germany during 2003-07. Journal of Antimicrobial Chemotherapy, 64, 2: 301-309

Schwarz S, Kehrenberg C, Walsh TR. 2001. Use of antimicrobial agents in veterinary medicine and food animal production. International Journal of Antimicrobial Agents, 17, 6: 431-7

Silbergeld E.K., Graham J., Price L.B. 2008. Industrial food animal production, antimicrobial resistance, and human health. Annual Review of Public Health, 29: 151-169

Smith KE, Besser JM, Hedberg CW, Leano FT, Bender JB, Wicklund JH, Johnson BP, Moore KA, Osterholm MT. 1999. Quinolone-resistant Campylobacter jejuni infections in Minnesota, 1992-1998. New England Journal of Medicine, 340, 20: 1525-32

Stalder T., Barraud O., Casellas M., Dagot C., Ploy M.C. 2012. Integron involvement in environmental spread of antibiotic resistance. Frontiers in Microbiology, 3: 1-14

Stobberingh E., Van den Bogaard A., London N., Driessen c., Top J., Willems R. 1999. Enterococci with glycopeptide resistance in turkeys, turkeyfarmers, turkeyslaughters and (sub)-urban residents in the south of The Netherlands: evidence for transmission of vancomycin resistance from animals to humans? Antimicrobial Agents and Chemotherapy, 43: 2215-2221

Stokes H.W., Hall R.M. 1989. A novel family of potentially mobile DNA elements encoding site-specific gene-integration functions: integrons. Molecular Microbiology, 3: $1669-1683$

Szmolka A., Fortini D., Villa L., Carattoli A., Anjum M.F., Nagy B. 2011. First report on IncN plasmid-mediated quinolone resistance gene qnrS1 in porcine Escherichia coli in Europe. Microbial Drug Resistance, 17, 4: 567-73

Tadesse D. A., Zhao S., Tong E., Ayers S., Singh A., Bartholomew M. J., Mcdermott P. F. 2012. Antimicrobial Drug Resistance in Escherichia coli from Humans and Food Animals, United States, 1950-2002. Emerging Infectious Diseases, 18: 741-749

Thaker M., Spanogiannopoulos P. 2010. The tetracycline resistome. Cellular and Molecular life Sciences, 67: 419-431

Trobos M, Lester CH, Olsen JE, Frimodt-Møller N, Hammerum AM. 2009. Natural transfer of sulphonamide and ampicillin resistance between Escherichia coli residing in the human intestine. Journal of Antimicrobial Chemotherapy, 63, 1: 80-6

Wasyl D., Hasman H., Cavaco L.M., Aarestrup F.M. 2012. Prevalence and characterization of cephalosporin resistance in nonpathogenic Escherichia coli from food-producing animals slaughtered in Poland. Microbial Drug Resistance, 18, 1: 79-82

Wilson M., Tam M. 2010. Raising Awareness for Prudent Use of Antibiotics in Animals. Position paper of the global Alliance for the Prudent Use of Antibiotics (APUA). Presented at WHO Expert meeting: Development of a policy-oriented guidance booklet for the European countries on Antimicrobial Resistance in a food safety perspective, Rome, Italy, 11-12 November 2010

Wise R. 2007. An overview of the Specialist Advisory Committee on Antimicrobial Resistance (SACAR). Journal of Antimicrobial Chemotherapy, 60: i5-i7

Xiao Y.H., Wang J., Li Y.; MOH National Antimicrobial Resistance Investigation Net. 2008. Bacterial resistance surveillance in China: a report from Mohnarin 2004-2005. 
European Journal of Clinical Microbiology \& Infectious Diseases, 27: 697-708

Zhao J., Chen Z., Chen S., Deng Y., Liu Y., Tian W., Huang X., Wu C., Sun Y., Sun Y., Zeng Z., Liu J.H. 2010. Prevalence and dissemination of $o q x A B$ in Escherichia coli isolates from animals, farmworkers, and the environment. Antimicrobial Agents and Chemotherapy, 54, 10: 4219-24 